\title{
ANALISIS RASIO KECUKUPAN MODAL PERBANKAN DAN PENGARUHNYA TERHADAP KINERJA PERBANKAN YANG TERDAPAT DI BURSA EFEK INDONESIA 2014
}

\author{
Zuriani Ritonga \\ Dosen Tetap Sekolah Tinggi Ilmu Ekonomi (STIE) Labuhanbatu
}

\begin{abstract}
ABSTRAK
Penelitian ini bertujuan untuk menganalisa pengaruh rasio kecukupan modal atau capital adequity ratio (CAR) terhadap profitabilitas yang dilihat dari aspek net interest margin yang terdaftar di Bursa Efek Indonesia.Hipotesis penelitian ini adalah rasio kecukupan modal berpengaruh signifikan terhadap net interest margin terdaftar di Bursa Efek Indonesia Periode 2008-2012.Populasi dalam penelitian ini adalah perusahaan perbankan yang tercatat di Bursa Efek Indonesia (BEI) dalam kurun waktu penelitian (tahun 20082012).Jumlah populasi dalam penelitian ini adalah sebanyak 31 bank. Teknikpengambilan sampel dilakukan melalui metode purposive sampling dengan tujuanuntuk mendapatkan sampel yang sesuai dengan tujuan penelitian. Teknik analisis data yang digunakan adalah analisis regresi sederhana dengan menggunakan program SPSS (Statistical Package For Social Science). Hasil penelitian menunjukkan bahwa tingkat kecukupan modalmempunyai hubungan yang signifikan terhadap kinerja perbankan Indonesia yang dilihat dari profitabilitas (NIM).
\end{abstract}

Kata kunci : Capital Adequty Ratio, Net Interest Margin. 


\section{Jurnal Ecobisma Vol 1 No. 12014}

\section{PENDAHULUAN}

Kinerja perbankan dapat dinilai dengan pendekatan analisa rasio keuangan. Tingkat kesehatan bank diatur oleh Bank Indonesia dalam Surat Edaran Bank Indonesia Nomor 6/23/DPNP 31 Mei 2004 kepada semua bank umum yang melaksanakan kegiatan usaha secara konvensional perihal sistem penilaian tingkat kesehatan bank umum dan Peraturan Bank Indonesia Nomor 6/10/PBI/2004 tanggal 12 April 2004 tentang sistem penilaian tingkat kesehatan bank umum, bank wajib melakukan penilaian tingkat kesehatan bank. Salah satu melihat kinerja perbankan adalah dengan melihat profitabilitas perbankan. Cara melihat profitabiltas perbankan dapat dilihat dari rasio profitabilitas seperti Return on Aset,, Return on Equity, Net Interest Margin, dan lain-lain.

Rasio profitabilitas merupakan rasio yang bertujuan untuk mengukur kemampuan bank untuk menghasilkan laba periode tertentu dan juga memberikan gambaran tentang tingkat efektifitas manajemen dalam melaksanakan kegiatan operasinya. Rasio profitabilitas yang penting bagi bank adalah NIM (Net Interest Margin).

Net Interest Margin (NIM), yaitu rasio yang digunakan untuk mengukur kemampuan manajemen bank dalam mengelola aktiva produktifnya untuk menghasilkan pendapatan bunga bersih. Pendapatan bunga bersih diperoleh dari pendapatan bunga dikurangi beban bunga.. Semakin besar NIM ini, maka itu berarti bank-nya semakin menguntungkan. Net interest Margin dikatakan baik apabila NIM nya di atas 6\%.

Rasio Kecukupan Modal atau Capital Adequacy Ratio (CAR) merupakan alat pengukur atau penilai kinerja bank, dengan mengetahui CAR suatu bank maka dapat diketahui kinerja bank yang bersangkutan. CAR dapat pula sebagai penilai permodalan dalam suatu bank karena modal merupakan faktor yang penting bagi bank dalam rangka pengembangan usahanya sehingga CAR dapat dijadikan sebagai alat penilaian untuk pengambilan keputusan investasi bagi bank yang mengeluarkan saham melalui kondisi dan prestasi keuangan bank yang tercermin dalam laporan keuangannya (Hasibuan.Malayu,2009). Begitu pentingnya modal bagi Bank, maka pengelola seringkali dihadapkan pada pilihan untuk memenuhi dan menjaga kecukupan modalnya, karena modal merupakan faktor penting dalam pengembangan usaha dan menampung kerugian. Hal inilah yang menyebabkan Bank kurang leluasa dalam memberikan pinjaman, padahal pemberian pinjaman kepada masyarakan merupakan salah satu pendapatan terbesar bagi Bank itu sendiri. Melihat kenyataan ini maka apabila modal yang dimiliki Bank besar maka kemampuan Bank dalam menyalurkan pinjaman juga besar sehingga kemampuannya untuk menciptakan laba juga bertambah.

Bank Indonesia (BI) sebagai otoritas perbankan di Indonesia, menetapkan batas minimum CAR di 8\%. Jadi kalau ada bank yang CAR-nya yang kurang dari 8\%, maka bank tersebut akan dilikuidasi. Peraturan ini tentu diperlukan, sebab bank adalah lembaga yang bertanggung jawab langsung kepada masyarakat banyak (bank kan tempat kita 'nitip' duit). Jika ada sebuah bank yang modalnya kurang dari $8 \%$ dari total asetnya, maka tentunya bank tersebut beresiko tinggi untuk gagal mengembalikan dana tabungan masyarakat.

Berdasarkan uraian beberapa penelitian diatas maka penulis tertarik untuk untuk meneliti rasio kecukupan modal perbankan yang memperhitungkan resiko kredit dan resiko pasar dan pengaruhnya terhadap kinerja perbankan yang dilihat dari fungsi intermediasi, 


\section{Jurnal Ecobisma Vol 1 No. 12014}

profitabilitas, dan resiko pada perbankan yang terdaftar di Bursa Efek Indonesia dari tahun 2008-2012.

\section{Perumusan Masalah}

Dari latar belakang masalah, perumusan dalam penelitian ini adalah "Apakah rasio kecukupan modal berpengaruh signifikan terhadap profitabilitas perbankan yang terdaftar di Bursa Efek Indonesia Periode 2008-2012”

\section{Tujuan dan Manfaat Penelitian}

Tujuan dilakukannya penelitian ini adalah :

Untuk menganalisa pengaruh rasio kecukupan modal yang memperhitungkan resiko kredit dan resiko pasar terhadap profitabilitas, Sedangkan manfaat dilaksanakannya penelitian ini, diharapkan dapat memberikan manfaat antara lain :

1. Bagi akademisi penelitian ini diharapkan dapat mendukung penelitian selanjutnya dan menjadi referensi

2. Sebagai sarana pengembangan ilmu pengetahuan dan penelitian ilmiah

3. Sebagai tambahan wawasan bagi peneliti

\section{Tinjauan Teoritis}

\section{Tingkat Kecukupan Modal Capital Adequacy Ratio (CAR)}

Kewajiban Penyediaan Modal Minimum (KPMM) atau yang umum diistilahkan sebagai Capital Adequacy Ratio (CAR) didefinisikan dalam Keputusan Bersama Menteri Keuangan Republik Indonesia dan Gubernur Bank Indonesia No. 53/KMK.017/1999 dan No. 31/12/KEP/GBI sebagai kewajiban bank umum untuk menyediakan modal minimum sebesar persentase tertentu dari aktiva tertimbang menurut risiko sebagaimana ditetapkan oleh Bank Indonesia.

Pada awal penetapannya di tahun 2001, CAR hanya mencakup penyediaan modal untuk risiko kredit saja. Namun seiring dengan perkembangan kondisi perekonomian global, Basel Committee on Banking Supervision melakukan revisi dengan membuat Market Risk Adjustments yang bertujuan untuk menyesuaikan peraturan permodalan dengan memasukkan unsur risiko pasar yang terkait dengan ekuitas, surat hutang, suku bunga, dan risiko komoditas. Berdasarkan aturan tersebut, maka Bank Indonesia menerbitkan Peraturan Bank Indonesia No. 5/12/PBI/2003 yang mewajibkan seluruh bank yang memenuhi kriteria untuk menambahkan risiko pasar di samping risiko kredit dalam perhitungan CAR di tahun 2005.

Salah satu aspek terpenting dalam melihat kesehatan perbankan nasional adalah dengan melihat permodalan dari perbankan itu sendiri. Hal ini salah satunya dapat dilihat dengan menggunakan rasio CAR (Capital Adequacy Ratio) atau kecukupan modal minimum. Modal adalah faktor utama pada sebuah perusahaan, karena melalui modal inilah perusahaan memiliki kemampuan untuk mengembangkan kegiatan bisnisnya. Menurut Muljono (2008:236), secara populer modal dapat didefenisikan sebagai : sejumlah dana yang ditanamkan ke dalam suatu perusahaan oleh para pemilikinya untuk pembentukan suatu 
badan usaha dan dalam perkembangannya modal tersebut dapat susut karena kerugian ataupun berkembang karena keuntungan - keuntungan yang diperolehnya.

Sedangkan fungsi modal menurut Muljono (2008:236) adalah:

a. sebagai ukuran kemampuan bank tersebut untuk menyerap kerugian yang tidak dapat dihindarkan,

b. sebagai sumber dana yang diperlukan untuk membiayai kegiatan usahanya sampai batas batas tertentu, karena sumber - sumber dana dapat juga berasal dari utang penjualan aset yang tidak dipakai, dll,

c. sebagai alat pengukur besar kecilnya kekayaan yan dimiliki oleh para pemegang saham,

d. dengan modal yang mencukupi, memungkinkan bagi manajemen bank yang bersangkutan untuk bekerja dengan efisiensi yang tinggi, seperti yang dikehendaki oleh para pemilik modal pada bank tersebut.

Modal terbagi atas:

1) Modal inti : modal disetor, cadangan, laba ditahan, agio saham, dll,

2) Modal pelengkap : berasal dari cadangan revaluasi aktiva tetap (selisih penilaian kembali aktiva tetap dengan persetujuan dirjen pajak), cadangan penghapusan aktiva yang diklasifikasikan (cadangan yang dibentuk dengan cara membebani lap. R/L tahun berjalan), modal kuasi / capital instrument (warkat yang memiliki sifat seperti modal), pinjaman subordinasi (pinjaman antar bank dengan persetujuan BI dengan jangka waktu min. 5 tahun dan bila pelunasan sebelum jatuh tempo harus persetujuan BI).

Pokok-pokok pengaturan dalam PBI nomor 10/15/PBI/2008 tentang Kewajiban Penyediaan Modal Minimum bank meliputi antara lain:

1). Kewajiban penyediaan modal minimum.

2). Bank wajib menyediakan modal minimum sebesar $8 \%$ dari Aktiva Tertimbang Menurut Risiko (ATMR). Kewajiban tersebut berlaku bagi Bank secara individu maupun Bank secara konsolidasi dengan Perusahaan Anak.

3) .Untuk mengantisipasi potensi kerugian sesuai profil risiko Bank, Bank Indonesia dapat mewajibkan Bank untuk menyediakan modal minimum lebih besar dari 8\%.

4). Komponen modal bagi Bank yang berkantor pusat di Indonesia terdiri dari modal inti dan modal pelengkap, serta modal pelengkap tambahan (yang dialokasikan hanya untuk menghitung risiko pasar) setelah memperhitungkan faktor-faktor tertentu yang menjadi pengurang modal.

Modal merupakan salah satu faktor yang penting bagi bank dalam mengembangkan usahanya (Siamat, 2011:99).Permodalan bagi bank sebagaimana perusahaan pada umumnya selain berfungsisebagai sumber utama pembiayaan terhadap kegiatan operasinalnya juga berperansebagai penyangga terhadap kemungkinan terjadinya kerugian. Modal yangdimiliki oleh suatu bank pada dasarnya harus cukup untuk menutupi seluruh risikousaha yang dihadapi oleh bank. Rasio kecukupan modal merupakan rasio yangbertujuan untuk memastikan bahwa bank dapat menyerap kerugian yang timbuldari aktivitas yang dilakukannya. Berdasarkan kesepakatan Basel I, rasiopermodalan minimum untuk industri perbankan diterapkan sebesar $8 \%$ (Idroes,2008:40).Permodalan bank yang cukup atau banyak sangat penting karena modal bank dimaksudkan untuk memperlancar operasional sebuah bank (Siamat, 2001:100).

Besarnya CAR dirumuskan sebagai berikut : 
Perhitungan kebutuhan modal didasarkan pada ATMR. Menurut Widjarnarko (1997) menyatakan bahwa: ATMR dalam perhitungan ini mencakup baik aktiva yang tercantum dalam neraca maupun aktiva yang bersifat administratif sebagaimana tercermin pada kewajiban yang masih bersifat kontinjen dan atau komitmen yang disediakan oleh bank bagi pihak ketiga. Terhadap masing-masing jenis aktiva tersebut ditetapkan bobot risiko yang besarnya didasarkan pada kadar risiko yang terkandung pada aktiva itu sendiri atau bobot risiko yang didasarkan pada golongan nasabah, penjamin, atau sifat barang jaminan.

\section{Net Interest Margin}

Pengertian Net Interest Margin (NIM) menurut Surat Edaran Bank Indonesia No 6/23/DPNP tanggal 31 Mei 2004 adalah "Net Interest Margin (NIM) merupakan perbandingan antara pendapatan bunga bersih terhadap rata-rata aktiva produktifnya."

Pengertian Net Interest Margin (NIM) menurut Selamet Riyadi (2006:21)

adalah perbandingan antara presentase hasil bunga terhadap total asset atau terhadap total earning assets." Pengertian Net Interest Margin (NIM) menurut Abra Puspa Ghani Talattov dan FX Sugiyanto (2008) adalah "NIM merupakan selisih bunga simpanan (dana pihak ketiga) dengan bunga pinjaman."

Dari penyataan diatas dapat disimpulkan bahwa pengertian Net InterestMargin (NIM) pada dasarnya adalah merupakan sebuah rasio keuangan yang merupakan hasil dari perbandingan antara pendapatan dari bunga terhadap aktiva, yang juga merupakan selisih antara bunga simpanan dan bunga pinjaman.

Kegunaan Net Interest Margin (NIM) menurut Koch dan Scott (2000)

adalah penting untuk mengevaluasi kemampuan bank dalam mengelola risiko terhadap suku bunga. Saat suku bunga berubah, pendapatan bunga dan biaya bunga bank akan berubah. Sebagai contoh saat suku bunga naik, baik pendapatan bunga maupun biaya bunga akan naik karena beberapa aset dan liability bank akan dihargai pada tingkat yang lebih tinggi."

\section{$\frac{\text { Pendapatan Bunga Bersih }}{\text { Aktiva Produktif }} \times 100 \%$}

Dari rumus diatas, maka dapat dijelaskan sebagai berikut, bahwa "Pendapatan Bunga Bersih" yang dimaksud merupakan hasil dari pendapatan bunga dikurangi dengan beban bunga. Sedangkan "Aktiva Produktif" yang dimaksud adalah rata-rata aktiva produktif yang digunakan, terdiri dari giro pada bank lain, penempatan pada bank lain dan Bank Indonesia, surat-surat berharga, surat-surat berharga yang dibeli dengan janji dijual kembali, Obligasi Pemerintah, wesel ekspor dan tagihan lainnya, tagihan derivatif, pinjaman dan pembiayaan syariah/piutang, tagihan akseptasi, penyertaan saham serta komitmen dan kontinjensi yang berisiko kredit:

\section{Kerangka Konseptual}




\section{Jurnal Ecobisma Vol 1 No. 12014}

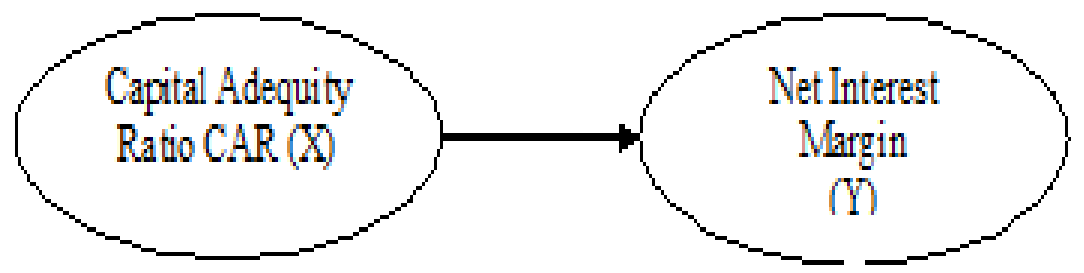

\section{Hipotesis Penelitian}

- Variabel rasio kecukupan modal berpengaruh signifikan terhadap net interest margin yang terdaftar di Bursa Efek Indonesia Periode 2008-2012?

\section{METODE PENELITIAN}

\section{Jenis dan Sumber Data}

Dalam penelitian ini data yang dipergunakan adalah data sekunder berupa data rasio-rasio keuangan masing-masing perusahaan perbankan yaitu Capital Adequacy Ratio(CAR, Net Interest Margin (NIM) yang terdaftar di Bursa Efek Indonesia. Data sekunder ini diperoleh dari pengamatan dari tahun 2008 sampai 2012.

\section{Sumber Data}

Sumber data dalam penelitian ini merupakan data sekunder yang diperoleh secara historis data profitabilitas dan kecukupan modal diambil dari laporan keuangan yang dipublikasikan pada sistus www.idx.co.id dan www.sahamok.com dari tahun 2008 s/d 2012. Pertimbangan dalam menggunakan metode sampel dalam kurun waktu 5 tahun ini adalah agar hasil penelitian ini lebih akurat.

\section{Populasi dan Sampel}

Populasi dalam penelitian ini adalah perusahaan perbankan yang tercatat di

Bursa Efek Indonesia (BEI) dalam kurun waktu penelitian (tahun 2008- 20012).Jumlah populasi dalam penelitian ini adalah sebanyak 31 bank. Teknikpengambilan sampel dilakukan melalui metode purposive sampling dengan tujuanuntuk mendapatkan sampel yang sesuai dengan tujuan penelitian. Metodepurposive sampling merupakan metode pengambilan sampel yang didasarkanpada beberapa pertimbangan atau kriteria tertentu. Kriteria yangakan dilakukan penelitian untuk dijadikan sampel penelitian

\section{Teknik Analisa Data}

Adapun model regresi sederhana yang digunakan adalah sebagaimana berikut :

$\mathrm{Y} \quad=$ Net Interest Margin

$$
\mathbf{Y}=\mathbf{a}+\mathbf{b X}+\mathbf{e}
$$

a $\quad$ Konstanta

$\mathrm{b} \quad=$ Koefisien Regresi Variabel $\mathrm{X}$

$\mathrm{X}=$ Variabel $C A R$ 
$\mathrm{e} \quad=$ Error Term

Kriteria pengujian hipotesis secara parsial adalah sebagai berikut :

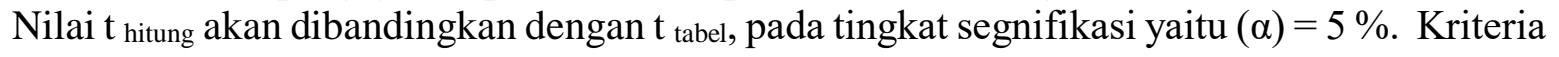
penilaian hipotesis pada uji t ini adalah :

$\mathrm{H}_{0}$ diterima jika : $-\mathrm{t}_{\text {tabel }} \leq \mathrm{t}$ hitung $\leq \mathrm{t}_{\text {tabel }}$

$\mathrm{H}_{1}$ diterima jika : $\mathrm{t}_{\text {hitung }}>\mathrm{t}$ tabel

Pembahasan

$\mathrm{t}$ hitung $\leq-\mathrm{t}$ tabel

Hasil penelitian menunjukkan bahwa hubungan antara rasio kecukupan modal berpengaruh positif dan signifikan terhadap net interest margin dengan signifikan 0,013. Hal ini berarti ada hubungan yang signifikan antara rasio kecukupan modal dengan memperhitungkan resiko kredit terhadap profitabilitas perbankan Indonesia yang terdaftar di Bursa Efek Indonesia. Hasil penelitian ini sejalan dengan hasil penelitian yang dilakukan oleh Ni luh dan Wayan (2014) yang menyatakan bahwa variabel rasio kecukupan modal memiliki pengaruh yang positif terhadap profitabilitas. Berdasarkan perhitungan secara parsial didapatt hitung sebesar 0,124 dan signifikansi sebesar 0,901. Hal ini menunjukkan bahwa rasio kecukupan modal berpengaruh positif terhadap profitabilitas, sehingga hipotesis dapat diterima. Namun pengaruh yang ditunjukkan adalah tidak signifikan, karena persentase rasio kecukupan modal yang tinggi dapat mempengaruhi kemampuan bank dalam melakukan ekspansi usahanya karena besarnya cadangan modal yang dimilki oleh perusahaan digunakan untuk menutupi risiko kerugian yang dalam hal ini adalah rasio kredit bermasalah. Terhambatnya ekspansi usaha akibat tingginya rasio kecukupan modal pada akhirnya akan mempengaruhi kinerja keuangan perbankan.

\section{KESIMPULAN DAN SARAN}

\section{Kesimpulan}

Secara parsial tingkat kecukupan modal (CAR) berpengaruh positif terhadap profitabilitas (NIM) . Artinya semakin tinggi rasio kecukupan modal maka semakin tinggi pula rasio profitabilitas perbankan yang terdaftar pada Burasa Efek Indonesia tahun 20082012.

\section{Saran}

Berdasarkan hasil penelitian dapat dikemukan beberapa saran sebagai berikut:

1. Pada penelitian ini lingkup penelitiaan hanya pada perusahaan perbankan yang terdaftar di Bursa Efek Indonesia, sehingga kedepan perlu di teliti lebih luas pada perusahaan perbankan yang terdaftar di Bursa Asia tenggara

2. Untuk penelitian selanjutnya peneliti dapat meneliti rasio kecukupan modal dari berbagai sektor industry seperti; pertambangan, pertanian, manufaktur dsb. 


\section{Jurnal Ecobisma Vol 1 No. 12014}

\section{DAFTAR PUSTAKA}

Abdullah, , 2005. Manajemen Perbankan, Cetakan Ketiga, UMM Press,. Malang Abdul Halim.2003. Analisis Invenstasi. Edisi Pertama. Salemba Empat: Jakarta. Agus Sartono. 2010.Manajemen Keuangan Teori dan Aplikasi (4 th ed.). Yogyakarta: BPFE. Almilia, Luciana Spica dan Herdiningtyas, Winny, 2005, "Analisis Rasio Camel Terhadap Prediksi Kondisi Bermasalah Pada Lembaga Perbankan Perioda20002002", Jurnal Akuntansi \& Keuangan, Vol. 7, No. 2, Hal. 131-147

Amriani, F. R. (2012). Analisis Pengaruh CAR, NPL, BOPO dan NIM terhadap LDR pada Bank BUMN Persero di Indonesia Periode 2006-2010. Makassar: Universitas Hasanuddin.

Awdeh, A., EL-Moussawi, C., \& Machrouh, F. (2011). The Effect of Capital Requirements on Banking Risk. International Research Journal of Finance and Economics, 66, 133-146.

Bank Indonesia, 2001, Surat Edaran Bank Indonesia Nomor 3/30/DPNP/2001 tanggal 14 Desember 2001

Bank Indonesia, 2004. Surat Edaran Bank Indonesia Nomor: 6/10/PBI/2004.

Bank Indonesia,2008, Laporan Keuangan Publikasi , www.bi.go.id , 2009, Laporan Keuangan Publikasi , www.bi.go.id , 2010, Laporan Keuangan Publikasi , www.bi.go. , 2011, Laporan Keuangan Publikasi , www.bi.go.id , 2012, Laporan Keuangan Publikasi,www.bi.go.id

Bennaceur, S., \& Goaied, M. (2008). The Determinants of Commercial Bank Interest Margin and Profitability: Evidence from Tunisia. Frontiers in Finance and Economics, 5 (1), $106-130$

Berger A. N. (1995). The Relationship Between Capital and Earnings in anking. Journal of Money, Credit, and Banking, 27 (2), 432-456 